\title{
Pengembangan instrumen tes kemampuan penalaran kuantitatif bagi siswa kelas VI SD/MI
}

\author{
Dzikra Fu'adiah \\ dzikra@stai-siliwangi.ac.id \\ Pendidikan Guru Madrasah Ibtidaiyah (PGMI), STAI Siliwangi Bandung
}

\begin{abstract}
ABSTRAK
Kemampuan penalaran kuantitatif menjadi dasar bagi siswa memahami dan mempelajari matematika dan ilmu pengetahuan lain. Kemampuan penalaran kuantitatif berhubungan dengan kemampuan menggali informasi tentang kuantitas tertentu yang berhubungan atau berubah atau bertransformasi ke kuantitas lain menuju kesimpulan dari suatu masalah. Ketersediaan tes kemampuan penalaran kuantitatif (TKPK) akan bermanfaat untuk mengukur kemampuan tersebut. Tujuan penelitian ini adalah mendeskripsikan proses pengembangan perangkat tes kemampuan penalaran kuantitatif dan kualitas tes kemampuan penalaran kuantitatif untuk siswa kelas VI MI/SD yang telah dikembangkan tersebut. Perangkat TKPK dikembangkan menggunakan metode penelitian pengembagan tes. Instrumen TKPK meliputi lembar soal (petunjuk peserta tes dan soal), lembar jawaban, pedoman penskoran, pedoman pengawas dan jawaban dan alternatif penyelesaian. Pengembangan TKPK siswa kelas VI MI/SD dilakukan dengan merancang dua rancangan, yaitu TKPK 1 dan TKPK 2 dan melalui tujuh tahap, yaitu (1) mendefinisikan indikator kemampuan penalaran kuantitatif, konten tes dan konteks masalah; (2) mengkonstruk kisi-kisi, format pertanyaan dan jawaban, bentuk penyelenggaraan dan cara penskoran; (3) menyusun butir soal dan pedoman penskoran; (4) menyusun petunjuk penyelenggaraan tes untuk pengawas tes serta petunjuk untuk peserta tes; (5) uji coba instrumen tes; (6) analisis butir soal secara kuantitatif; dan (7) merevisi butir soal. Dua rancangan TKPK yang dikembangkan memiliki kualitas yang cukup baik.
\end{abstract}

Kata kunci: penalaran kuantitatif, instrumen tes

\section{Developing Test Instrument of Quantitative Reasoning Skills for Grade 6 SD/MI Students}

\begin{abstract}
Reasoning ability is the basis for students to understand and study mathematics and other sciences. Quantitative reasoning ability relates to the ability to explore information about certain quantities that relate or change or transform into other quantities towards the conclusion of a problem. The availability of a reasoning ability test (TKPK) will be useful to measure this ability. The purpose of this research is the process of developing the quantitative reasoning ability test kit and the quality of the quantitative reasoning test describing the students of class VI MI/SD that have been developed. The TKPK toolkit was developed using the test development research method. The TKPK instrument includes question sheets (test-takers instructions and questions), answer sheets, scoring guidelines, supervisor guidelines, and answers and alternative solutions. The development of TKPK for grade VI MI/SD students was carried out by designing two designs, namely TKPK 1 and TKPK 2, and through seven stages, namely (1) defining indicators of quantitative reasoning ability, test content, and problem context; (2) constructing grids, formats and answers, forms of administration and scoring methods; (3) compiling questions and scoring guidelines; (4) prepare instructions for administering tests for test supervisors as well as for instructions for test-takers; (5) testing of test instruments; (6) quantitative item analysis; and (7)
\end{abstract}


revise the question items. The two TKPK designs that have been developed are of fairly good quality.

Keywords: quantitative reasoning, test instrument

Received: Nov 23 ${ }^{\text {rd }}, 2021 \quad$ Reviewed: Dec 10 $10^{\text {th }}, 2021 \quad$ Accepted: Jan 23 $3^{\text {rd }}, 2022 \quad$ Published: Jan 31st, 2022

\section{PENDAHULUAN}

Kemampuan penalaran kuantitatif merupakan kemampuan dasar bagi siswa untuk memahami dan mempelajari matematika dan ilmu pengetahuan lain. Anakanak telah menggunakan penalaran kuantitatif untuk memperkirakan hasil perhitungan sederhana dalam kehidupan sehari-hari (Nunes \& Bryant, 2021). Bahkan, penalaran kuantitatif dapat dikembangkan saat siswa mulai mengenal bilangan (Fu'adiah, 2018). Penekanan awal pada pengembangan kemampuan siswa memahami, menalar dan memanipulasi ide dan hubungan kompleks merupakan tujuan pengajaran matematika, seperti perhitungan dan penalaran kuantitatif. Siswa yang mengembangkan kemampuan penalaran kuantitatif untuk memproses hubungan antara kuantitas-kuantitas akan memiliki dasar konseptual untuk belajar dan memahami pengetahuan berbeda (Jack \& Thompson, 2017).

Siswa memiliki kesulitan dalam menyelesaikan masalah matematis dan kemampuan penalaran kuantitatidf dapat digunakan untuk mengatasi kesulitan tersebut. Dalam menyelesaikan masalah, siswa seharusnya mampu menafsirkan data dan menggunakan pemodelan matematika, namun kedua kemampuan itu sulit untuk siswa kuasai (Hoffman et al., 2016). Dengan menguasai kemampuan penalaran kuantitatif akan menjadi alat bantu menjelaskan atau memecahkan suatu masalah (Firdaus, 2013).

Kemampuan siswa bernalar kuantitatif diperlukan dalam memahami dan menerapkan konsep-konsep matematika dan keterampilan untuk memecahkan masalah dunia nyata. Tahap yang harus dilalui dalam menyelesaikan masalah dengan menggunakan penalaran kuantitatif, yaitu menentukan pengetahuan apa yang relevan dengan masalah; memperkirakan proses apa saja yang harus dilalui untuk dapat mengantarkan ke solusi yang mungkin sesuai dengan permasalahan; dan menggambarkan kebenaran dan kegunaan dari jawaban atau solusi yang diperoleh (Firdaus, 2013). 
Kemampuan penalaran kuantitatif berhubungan dengan kemampuan menggali informasi tentang kuantitas tertentu yang berhubungan atau berubah atau bertransformasi ke kuantitas lain menuju kepada suatu kesimpulan terhadap suatu masalah (Agustinus, 2013). Contoh proses menghubungkan kuantitas, misalnya seorang siswa membandingkan kuantitas-kuantitas secara aditif, dengan membandingkan seberapa lebih tinggi seseorang dengan orang lain, atau secara multiplikatif, dengan menentukan berapa kali lebih besar satu objek terhadap objek lain (Ellis, 2011). Kuantitas tersebut sangat berhubungan dengan bilangan dan perhitungan bilangan yang dipelajari dalam mata pelajaran matematika, namun penalaran kuantiatif pada dasarnya merupakan hal yang berbeda dengan pengetahuan konten matematika secara konsep dam praktek. Melakukan penalaran kuantitatif memerlukan konten matematika sebagai alat dan cara untuk mengkomunikasikan kuantitatas-kuantitas dan hubungannya yang kompleks menjadi lebih sederhana. Penalaran kuantitatif pun membutuhkan kemampuan matematis seperti kemampuan dalam aritmetika, mengolah persentase dan grafik, estimasi, pengolahan data dan peluang, dasar pengukuran dalam geometri, dan pemahaman terhadap pola (Hallet dalam Grawe, 2011).

Kapan seseorang mulai mampu bernalar secara kuantitatif telah diteliti oleh Carroll (1993). Penalaran kuantitatif sudah ada pada anak usia lima tahun sampai dewasa. Oleh karena itu, siswa MI/SD mampu melalukan penalaran kuantitatif. Kemampuan penalaran kuantitatif siswa memiliki tiga tingkatan menurut Tian \& Huang (2009) yaitu, tingkat perhitungan abstrak (tinggi), tingkat perhitungan dugaan (sedang) dan tingkat perhitungan lateral (rendah). Tingkatan inilah yang menjadi dasar bahwa kemampuan penalaran kuantitatif siswa berbeda-beda. Tingkatan tersebut diklasifikasikan berdasarkan benar atau tidaknya jawaban dan alasan siswa terhadap suatu masalah yang melibatkan kuantitas.

Namun kenyataannya, siswa tidak memperhatikan kuantitas-kuantitas dan hubungan-hubungannya langsung, kemudian hanya melakukan perdebatan tak mendasar tentang pemilihan bilangan-bilangan dan operasi dalam menyelesaikan masalah (Harel \& Sowder, 1998). Sebagian besar siswa MI/SD hanya menghafalkan algoritma atau metode dalam menyelesaikan masalah tanpa memahami dengan baik hubungan antara informasi-informasi yang diberikan dengan pertanyaan dalam masalah. Kendala tersebut tampaknya disebabkan oleh kemampuan penalaran kuantitatif siswa yang rendah. Namun, anggapan kemampuan penalaran kuantitatif siswa MI/SD yang rendah hanya anggapan yang tidak didukung oleh data yang valid. 
Belum ada pengukuran yang komprehensif dan khusus untuk mengukur tingkat kemampuan penalaran kuantitatif siswa MI/SD.

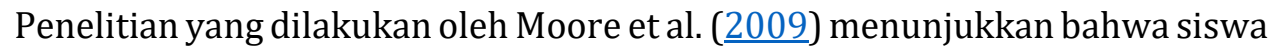
yang memiliki kemampuan penalaran kuantitatif tingkat lanjut akan dapat memecahkan masalah dengan lebih bermakna. Demikian pula, penelitian lain yang dilakukan Moore et al. (2009) telah menunjukkan bahwa penalaran kuantitatif efektif digunakan dalam penyelesaian masalah. Dalam penelitian yang dilakukan oleh Kabael \& Akin (2016) menyelidiki strategi dan kemampuan penalaran kuantitatif yang digunakan dalam memecahkan masalah aljabar. Kemampuan penalaran kuantitatif memainkan peran penting dalam penggunaan strategi aritmatika dan aljabar secara efektif dalam proses pemecahan masalah.

Untuk mengetahui tingkat kemampuan penalaran kuantitatif seseorang, maka diperlukan alat yang andal dan akurat untuk mengukur kemampuan penalaran kuantitatif. Menghasilkan penilaian yang adil dan andal diperlukan kejelasan apa yang harus diukur dan bagaimana cara mengukur dan menafsirkan data penilaian yang dihasilkan (Dwyer et al., 2003). Tes merupakan salah satu alat yang digunakan untuk mengetahui atau mengukur keadaan tertentu peserta tes dengan cara dan aturan-aturan yang sudah ditentukan. Pengembangan perangkat tes kemampuan penalaran kuantitatif siswa MI/SD perlu dilakukan karena perangkat tes kemampuan penalaran kuantitatif bagi siswa MI/SD belum ada di Indonesia, kebanyakan soal-soal hanya menguji kemampuan kuantitatif saja bukan penalaran kuantitatif. Bahkan, soal-soal tersebut ada di tes masuk perguruan tinggi.

Perangkat tes kemampuan penalaran kuantiatif dikembangkan sesuai dengan indikator kemampuan penalaran kuantitatif. Apakah perangkat tes memiliki kualitas yang baik digunakan untuk mengukur kemampuan penalaran kuantitatif siswa MI/SM perlu diuji. Oleh karena itu, penelitian ini dilakukan untuk mengembangkan tes kemampuan penalaran kuantitatif siswa MI/SD, khususnya kelas VI dalam matapelajaran Matematika, dan menguji kualitas perangkat tes tersebut sehingga layak digunakan untuk mengukur kemampuan penalaran kuantitatif siswa kelas VI MI/SD.

Berdasarkan latar belakang yang telah diuraikan, pertanyaan penelitian ini adalah: (1) Bagaimana proses pengembangan perangkat tes kemampuan penalaran kuantiatif untuk siswa kelas VI MI/SD? (2) Bagaimana kualitas soal tes kemampuan penalaran kuantitatif untuk siswa kelas VI MI/SD? 


\section{METODE PENELITIAN}

Jenis penelitian ini adalah penelitian pengembangan tes. Penelitian pengembangan tes ini menghasilkan suatu perangkat tes yaitu perangkat tes kemampuan penalaran kuantitatif (TKPK) untuk siswa kelas VI MI/SD. Untuk mendapatkan tes yang memuat butir soal baku yang berkualitas, maka perlu dilakukan pengujian baik secara teoritis/kualitatif maupun empiris/kuantitatif. Pembuatan perangkat tes harus melewati proses pengembangan dan pengujian. Pengembangan tes menggunakan 7 langkah yang dikembangkan oleh McIntire et al., (2006) dan diilustrasikan dengan diagram alir pada gambar 1 berikut:

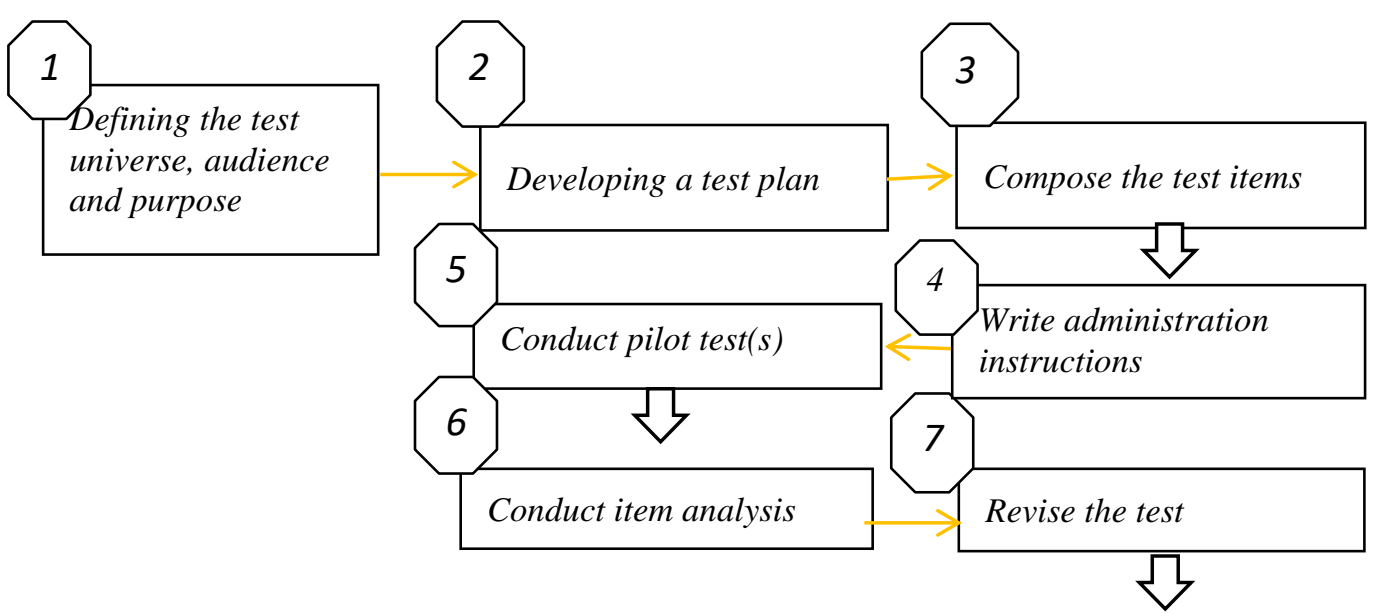

Gambar 1. Diagram Alir Langkah Pengembangan Tes

\section{Defining the test universe, audience, and purpose}

Tahap pertama yang harus dilakukan oleh seorang pengembang tes adalah mendefinisikan kompetensi yang diharapkan dapat ditunjukkan oleh peserta tes, karakteristik kemampuan peserta tes dan tujuan tes itu sendiri.

\section{Developing a test plan}

Hal-hal yang direncanakan dalam tahap ini meliputi konstruk (kisi-kisi), format pertanyaan dan jawaban, bentuk penyelenggaraan dan cara penyekorannya.

3. Composing the test items

Pada tahap ini disusun butir-butir soal tes sesuai dengan format tes dan indikator pencapaian kompetensi yang telah dirancang dan pedoman penskoran. Sebelum diuji coba, butir soal perlu ditelaah secara kualitaif oleh ahli (expert judgement) yaitu ahli materi dari bidang studi yang sama, ahli pengukuran dan ahli bahasa. Ahli materi berkewajiban mereview substansi keilmuan soal tes, ahli konstruksi tes berkewajiban mengkoreksi teknik penulisan soal yang benar dan ahli bahasa 
mengkoreksi kejelasan hal yang ditanyakan, penggunaan bahasa baku, dan struktur kalimat.

\section{Writing the administration instructions}

Pada tahap ini disusun petunjuk penyelenggaraan tes yang terdiri dari petunjuk untuk penyelenggara dan pengawas ujian serta petunjuk untuk peserta tes itu sendiri.

\section{Conduct piloting test}

Perangkat tes yang telah disusun kemudian diuji coba untuk memperoleh data empiris yang berguna pada pengujian kualitas butir tes. Subjek yang menjadi sasaran uji coba tes harus memiliki karakteristik yang sama dengan sasaran tes yang sebenarnya.

\section{Conduct item analysis}

Setelah uji coba tes dilakukan, untuk mengetahui kualitas butir-butir tes tersebut sudah baik atau belum, maka perlu dilakukan analisis butir secara kuantitatif untuk mengetahui validitas, realibilitas tingkat kesukaran, dan daya pembeda.

\section{Revising the test}

Hasil analisis butir merevisi butir yang kurang baik. Pengambilan keputusan terhadap butir-butir yang perlu direvisi dilakukan dengan menggunakan beberapa pertimbangan hasil analisis validitas $\left(r_{x y}\right)$, realibilitas $\left(r_{11}\right)$, tingkat kesukaran $(P)$, dan daya pembeda $(D P)$. Apabila dua dari tiga kriteria butir tes yang baik dapat terpenuhi atau konsisten, maka butir tes tersebut dapat digunakan. Sebaliknya apabila dua dari tiga kriteria butir tidak dapat memenuhi kualitas butir yang baik maka butir tes perlu diganti atau direvisi.

Penelitian ini dilaksanakan di Madrasah Ibtidaiyah (MI) Asih Putra yang beralamat Kota Cimahi, Jawa Barat. Penelitian bertujuan mengembangkan tes kemampuan penalaran kuantitatif siswa kelas VI SD sehingga subjek penelitian ini adalah siswa kelas VI MI Asih Putra sebanyak 23 orang siswa. Pemilihan subjek tersebut menggunakan teknik Purposive Sampling. Teknik Purposive Sampling digunakan karena peneliti mempertimbangkan memilih subjek yang familiar dan terbiasa dengan soal-soal penalaran secara umum. Setelah observasi pendahuluan ke beberapa MI sekitar Kota Cimahi, peneliti memutuskan subjek penelitian adalah siswa MI Asih Putra. Teknik pengumpulan data pada penelitian ini dengan melakukan tes dan menggunakan angket validasi dan konstruk butir soal. Validasi Tes dilakukan untuk mengujicoba butir soal yang sudah validasi isi dan konstruk butir soal TKPK 
digunakan untuk menilai kesesuaian antara indikator, materi, dan soal tes. Validasi isi dilakukan dalam penelitian ini untuk menelaah: (1) kesesuaian masalah dengan konten matematika yang telah pernah dipelajari oleh siswa kelas VI MI/SD; (2) relevansi masalah dengan konteks sehari-hari; (3) relevansi masalah dengan masingmasing indikator kemampuan penalaran kuantitatif. Sementara validasi konstruk digunakan untuk menelaah: (1) informasi dan pertanyaan pada masalah mudah dimengerti, jelas tertangkap maknanya, dan tidak menimbulkan penafsiran ganda; (2) rumusan soal menggunakan kalimat tanya atau perintah yang menuntut uraian solusi; (3) kesesuaian bahasa yang digunakan pada masalah dengan kaidah tata Bahasa Indonesia yang baik dan benar; (4) rumusan masalah menggunakan kata atau kalimat yang tidak menimbulkan makna atau penafsiran ganda; (5) rumusan masalah menggunakan bahasa yang sederhana, komutatif, mudah dipahami dan dikenal oleh siswa kelas VI MI/SD. Validasi dilakukan oleh satu orang validator yang ahli di bidang pendidikan matematika dimana beliau adalah dosen IKIP Siliwangi yang memiliki perhatian pada evaluasi pada ranah kognitif siswa.

Analisis data dilakukan secara kuantitatif dan kualitatif.

1. Analisis data kualitatif dilakukan untuk menganalisis data hasil validasi isi dan konstruk butir soal dan studi dokumentasi proses pengembangan perangkat TKPK.

2. Analisis data kuantitatif digunakan untuk menganalisis data hasil uji coba soal untuk mengukur kualitas butir soal dengan menggunakan rumus-rumus untuk menguji validitas $\left(r_{x y}\right)$, realibilitas $\left(r_{11}\right)$, tingkat kesukaran $(P)$, dan daya pembeda $(D P)$. Sedangkan untuk validasi tes bisa dibuktikan dengan cara mengkorelasikan skor tes peserta tes pada TKPK dengan skor tes peserta tes pada tes yang pernah diikuti sebelumnya (teknik concurrent validity).

\section{HASIL DAN PEMBAHASAN}

\section{Proses Pengembangan Perangkat (TKPK)}

Penelitian ini bertujuan untuk mengembangkan Tes Kemampuan penalaran kuantitatif (TKPK). Perangkat tes meliputi lembar soal (petunjuk peserta tes dan soal), lembar jawaban, pedoman penskoran, pedoman pengawas dan jawaban dan alternatif penyelesaian. Perangkat tes dikembangkan dengan menggunakan sepuluh tahapan (McIntire et al., 2006). Tahapan yang dikembangkan oleh McIntire merupakan tahapan khusus untuk mengembangkan suatu instrumen tes. Tahapan 
yang dilakukan dalam penelitian ini hanya hingga pada tahap ketujuh yaitu tahap Revising the test. Tahap kedepalan hingga kesepuluh akan dilakukan pada pengembangaan berikutnya. Terdapat dua paket TKPK yang bersesuain yang dikembangkan, yang disebut dengan TKPK 1 dan TKPK 2.

\section{Defining the Test Universe, Audience, and Purpose}

Pada tahap pertama, indikator kemampuan penalaran kuantitatif, konten tes dan konteks masalah yang digunakan dalam mengembangkan TKPK didefinisikan. Pendefinisian tersebut dilakukan dengan melakukan kajian pustaka.

Berdasarkan enam kemampuan dalam penalaran kuantitatif dan fokus tes kemampuan penalaran kuantitatif menurut Dwyer et al. (2003) dan tingkat kemampuan penalaran kuantitatif menurut Tian \& Huang (2009), peneliti menyusun indikator kemampuan penalaran kuantitatif. Indikator kemampuan penalaran kuantitatif adalah sebagai berikut:

a. memahami informasi yang diberikan dalam masalah baik secara eksplisit maupun implisit dalam berbagai bentuk;

b. memahami masalah yang akan diselesaikan;

c. menginterpretasikan, mengkomunikasikan dan menyimpulkan informasi kuantitatif dalam masalah baik yang dinyatakan secara eksplisit maupun implisit yang diketahui dari masalah;

d. memecahkan masalah menggunakan metode (dalam penelitian ini, metode aritmetika atau geometri);

e. memilih dan menggunakan strategi komputasi untuk memecahkan masalah;

f. menentukan tingkat akurasi perhitungan yang diperlukan atau kesesuaian menggunakan estimasi untuk memeriksa jawaban;

g. mengetahui keterbatasan metode matematika yang digunakan dalam memecahkan masalah.

Penalaran kuantitatif sangat erat kaitannya dengan matematika, namun tes kemampuan penalaran kuantiatif tidak menilai pengetahuan seseorang terhadap konten matematika. Menurut Dwyer et al. (2003) konten merupakan hal yang berkenaan dengan pengetahuan dan keterampilan yang dibutuhkan untuk menjawab pertanyaan suatu tes. Konten matematika hanya digunakan sebagai alat untuk menalar suatu masalah. GRE (Graduate Record Examinations) salah satu tes kemampuan akademik populer yang memuat tes kemampuan penalaran kuantitatif. Dalam penelitian ini konten tes kemampuan penalaran kuantitatif hanya memuat 
aplikasi konsep dasar aritmetika, aljabar, geometri dan analisis data yang disesuaikan dengan standar kompetensi lulusan MI/SD yang tertuang dalam Peraturan Menteri Pendidikan Nasional Republik Indonesia No. 23 Tahun 2006 (Standar Kompetensi Lulusan Untuk Satuan Pendidikan Dasar Dan Menengah, 2006).

Aritmetika memuat topik bilangan dan operasi. Topik bilangan dan operasi berhubungan dengan pemahaman terhadap bilangan yang membutuhkan kemampuan melakukan operasi aritmetika, memperkirakan reliabilitas, mempertimbangkan kemasukakalan penyelesaian, memahami satuan-satuan besaran, dan berfikir proposional. Beberapa topik yang masuk ke dalam kategori topik aritmetika adalah persentase, perbandingan, nilai tempat dan perkalian dan sisa hasil pembagian. Konten aljabar berhubungan dengan kemampuan menerjemahkan situasi masalah ke dalam representasi aljabar dan kemampuan menggunakan representasi masalah tersebut untuk menyelesaikan masalah. Beberapa topik yang termasuk konten aljabar adalah persamaan linear, manipulasi bentuk aljabar, dan menerjemaahkan soal cerita menjadi pernyataan aljabar. Geometri memuat topik geometri dan pengukuran. Topik yang masuk ke dalam konten geometri dan pengukuran adalah luas dan keliling bangun datar, volume bangun ruang dan sudut suatu bidang. Konten analisis data memuat topik membaca, memahami dan menarik kesimpulan dari informasi yang direpresentasikan dalam bentuk tabel dan grafik (Dwyer et al., 2003).

Konteks masalah yang digunakan dalam tes kemampuan penalaran kuantitatif menurut Dwyer et al. (2003) terbatas hanya pada keadaan masalah yang familiar bagi semua peserta tes. Konteks yaitu kondisi yang berkenaan dengan keadaan yang digambarkan dalam soal tes kemampuan penalaran kuantitatif yang ditujukan untuk siswa kelas VI MI/SD. Sehingga, konteks masalah dalam tes kemampuan penalaran kuantitatif penelitian ini adalah masalah yang familiar bagi siswa kelas VI MI/SD.

\section{Developing a Test Plan}

Hal-hal yang direncanakan dalam tahap ini meliputi konstruk (kisi-kisi), format pertanyaan dan jawaban, bentuk penyelenggaraan dan cara penskoran. Pada tahap ini, draf 1 kisi-kisi, format soal dan jawaban, dan pedoman penskoran dikembangkan berdasarkan kajian pustaka.

Berikut kisi-kisi soal yang digunakan dalam pengembangan tes kemampuan penalaran kuantitatif ini. 
Tabel 1. Kisi-kisi Soal

\begin{tabular}{|c|c|c|c|c|c|}
\hline & $\begin{array}{l}\text { Indikator Kemampuan } \\
\text { Penalaran Kuantiatif }\end{array}$ & $\begin{array}{c}\text { Konten } \\
\text { Matematika }\end{array}$ & Konteks & $\begin{array}{l}\text { Format } \\
\text { Soal dan } \\
\text { Jawaban }\end{array}$ & $\begin{array}{l}\text { No. } \\
\text { Soal }\end{array}$ \\
\hline 1. & $\begin{array}{l}\text { memahami informasi } \\
\text { yang diberikan dalam } \\
\text { masalah baik secara } \\
\text { eksplisit maupun implisit }\end{array}$ & $\begin{array}{l}\text { Aritmetika: } \\
\text { kelipatan dan } \\
\text { operasi } \\
\text { bilangan asli. }\end{array}$ & $\begin{array}{l}\text { Merawat } \\
\text { binatang } \\
\text { peliharaan }\end{array}$ & Uraian & $\begin{array}{l}\text { TKPK } 1 \\
\text { No. } 1\end{array}$ \\
\hline 3. & $\begin{array}{l}\text { dalam berbagai bentuk } \\
\text { (rumus, kata-kata, tabel, } \\
\text { grafik); } \\
\text { memahami masalah yang } \\
\text { akan diselesaikan; } \\
\text { menginterpretasikan, } \\
\text { mengkomunikasikan dan }\end{array}$ & $\begin{array}{l}\text { Aritmetika: } \\
\text { pemahaman } \\
\text { dan operasi } \\
\text { bilangan. }\end{array}$ & $\begin{array}{l}\text { Mengatur } \\
\text { buku catatan } \\
\text { sekolah; } \\
\text { Membagi } \\
\text { buah; } \\
\text { Potongan } \\
\text { harga lego. } \\
\end{array}$ & Uraian & $\begin{array}{l}\text { TKPK } 2 \\
\text { No. } 1 \\
\text { TKPK } 1 \\
\text { No. } 3 \\
\text { TKPK } 1 \\
\text { No. } 5\end{array}$ \\
\hline & $\begin{array}{lr}\text { menyimpulkan informasi } \\
\text { kuantitatif } & \text { dalam } \\
\text { masalah baik } & \text { yang } \\
\text { dinyatakan } & \text { secara }\end{array}$ & $\begin{array}{l}\text { Aritmetika: } \\
\text { pemahaman } \\
\text { dan operasi } \\
\text { bilangan. } \\
\end{array}$ & & Uraian & \\
\hline 4 & $\begin{array}{l}\text { eksplisit maupun implisit } \\
\text { yang diketahui dari } \\
\text { masalah; } \\
\text { memecahkan masalah }\end{array}$ & $\begin{array}{l}\text { Geometri: } \\
\text { menghitung } \\
\text { luas bangun } \\
\text { datar }\end{array}$ & $\begin{array}{l}\text { uat } \\
\text { uk arah } \\
\text { sendiri }\end{array}$ & Uraian & $\begin{array}{l}\text { TKPK } 2 \\
\text { No. } 2\end{array}$ \\
\hline 5. & $\begin{array}{l}\text { menggunakan metode } \\
\text { (dalam penelitian ini, } \\
\text { metode aritmetika atau } \\
\text { geometri); } \\
\text { memilih } \\
\text { menggunakan strategi } \\
\text { komputasi untuk } \\
\text { memecahkan masalah; } \\
\text { menentukan tingkat }\end{array}$ & $\begin{array}{l}\text { Statistika: } \\
\text { menginterpet } \\
\text { asi banyak } \\
\text { data }\end{array}$ & $\begin{array}{l}\text { Makanan } \\
\text { favorit di } \\
\text { kantin; } \\
\text { Jumlah } \\
\text { anggota } \\
\text { perkumpulan } \\
\text { sepeda } \\
\text { bedasarkan } \\
\text { jenis sepeda }\end{array}$ & Uraian & $\begin{array}{l}\text { TKPK } 1 \\
\text { No. } 3 \\
\text { dan } \\
\text { TKPK } 2 \\
\text { No. } 4\end{array}$ \\
\hline & $\begin{array}{l}\text { akurasi perhitungan yang } \\
\text { diperlukan ran } \\
\text { kesesuaian menggunakan } \\
\text { estimasi }\end{array}$ & $\begin{array}{l}\text { Aljabar: titik } \\
\text { potong dua } \\
\text { garis lurus. }\end{array}$ & $\begin{array}{l}\text { Perjalanan } \\
\text { dari rumah ke } \\
\text { sekolah }\end{array}$ & Uraian & $\begin{array}{l}\text { TKPK } 1 \\
\text { No. } 4 \\
\text { TKPK } 2 \\
\text { No. } 5\end{array}$ \\
\hline 7. & $\begin{array}{l}\text { memeriksa jawaban; } \\
\text { mengetahui keterbatasan } \\
\text { metode matematika yang } \\
\text { digunakan dalam } \\
\text { memecahkan masalah. }\end{array}$ & $\begin{array}{l}\text { Geometri : } \\
\text { volume } \\
\text { bangun ruang }\end{array}$ & $\begin{array}{l}\text { Memenuhi } \\
\text { kotak dengan } \\
\text { kubus satuan }\end{array}$ & Uraian & $\begin{array}{l}\text { TKPK } 1 \\
\text { No. } 2\end{array}$ \\
\hline
\end{tabular}

Bentuk penyelenggaraan tes adalah dengan menyelenggarakan tes tertulis dan cara penskoran dengan berpedoman pada pedoman penskoran dan kunci dan alternatif jawaban yang merupakan bagian dari perangkat TKPK dikembangkan dalam penelitian ini. 


\section{Composing the Test Items}

Peneliti mengembangkan dua rancangan soal, TKPK 1 dan TKPK 2 yang masingmasing terdiri atas lima soal. Kedua rancangan disusun dengan konten yang serupa dan diperkirakan dengan tingkat kesulitan yang setara. Pada tahap ini disusun butirbutir soal tes sesuai dengan format tes dan indikator pencapaian kompetensi yang telah dirancang dan disusun pula pedoman penskoran.

Sebelum diuji coba, butir soal perlu ditelaah secara kualitaif oleh ahli (expert judgement) yaitu ahli materi dari bidang studi yang sama, ahli pengukuran dan ahli bahasa. Ahli materi berkewajiban mereview substansi keilmuan soal tes, ahli konstruksi tes berkewajiban mengkoreksi teknik penulisan soal yang benar dan ahli bahasa mengkoreksi kejelasan hal yang ditanyakan, penggunaan bahasa baku, dan struktur kalimat. Dua rancangan soal berupa draf 1 TKPK 1 dan draf 1 TKPK 2 divalidasi pula oleh guru matematika MI kelas VI sebagai praktisi. Penelahaan dan validasi dilakukan dengan menggunakan pedoman yang dipersiapkan oleh peneliti. Hasil penelahaan dan validasi oleh ahli dan praktisi yang memuat penilaian dan saran menjadi dasar bagi peneliti untuk menyempurnakan kedua rancangan soal dan kemudian menghasilkan draf 2 TKPK 1 dan draf 2 TKPK 2.

Pedoman penskoran tes kemampuan penalaran kuantitatif disajikan dalam Tabel 2 berikut.

Tabel 2. Pedoman penskoran penalaran kuantitatif

\begin{tabular}{|c|c|c|}
\hline Tingkat & Skor & Indikator \\
\hline $\begin{array}{l}\text { Perhitungan } \\
\text { Abstrak }\end{array}$ & $\begin{array}{l}3 \\
3\end{array}$ & $\begin{array}{l}\text { Tahap 1. Memahami dan menentukan masalah. } \\
\text { - memahami dengan lengkap dan tepat informasi dalam } \\
\text { soal baik yang dinyatakan secara eksplisit maupun } \\
\text { implisit dalam berbagai bentuk (rumus, kata-kata, tabel, } \\
\text { grafik); } \\
\text { - memahami dengan lengkap dan tepat masalah yang akan } \\
\text { diselesaikan; } \\
\text { - menginterpretasikan, mengkomunikasikan dan } \\
\text { menyimpulkan dengan benar dan tepat informasi } \\
\text { kuantitatif yang mungkin berhubungan atau berubah atau } \\
\text { bertransformasi ke kuantitas lain baik yang dinyatakan } \\
\text { secara eksplisit maupun implisit; }\end{array}$ \\
\hline & 3 & $\begin{array}{l}\text { Tahap 2. Memecahkan masalah } \\
\text { - memecahkan masalah menggunakan metode yang benar } \\
\text { dan tepat (yaitu metode aritmetika, aljabar, geometri, atau } \\
\text { statistik); }\end{array}$ \\
\hline
\end{tabular}




\begin{tabular}{|c|c|c|}
\hline Tingkat & Skor & Indikator \\
\hline & & $\begin{array}{l}\text { - memilih dan menggunakan strategi komputasi yang } \\
\text { benar, efisien dan tepat untuk memecahkan masalah. }\end{array}$ \\
\hline & 3 & $\begin{array}{l}\text { Tahap 3. Memahami hasil } \\
\text { - menentukan tingkat akurasi perhitungan yang diperlukan } \\
\text { atau kesesuaian menggunakan estimasi untuk memeriksa } \\
\text { jawaban dengan tepat; } \\
\text { - mengenali keterbatasan metode matematis yang } \\
\text { digunakan dengan tepat. }\end{array}$ \\
\hline \multirow[t]{3}{*}{$\begin{array}{l}\text { Perhitungan } \\
\text { Dugaan }\end{array}$} & 2 & $\begin{array}{l}\text { Tahap 1. Memahami dan menentukan masalah. } \\
\text { - memahami dengan sebagian atau tidak lengkap dan tidak } \\
\text { tepat memahami informasi dalam soal baik yang } \\
\text { dinyatakan secara eksplisit maupun implisit dalam } \\
\text { berbagai bentuk (rumus, kata-kata, tabel, grafik); } \\
\text { - memahami dengan sebagian atau tidak lengkap dan tidak } \\
\text { tepat masalah yang akan diselesaikan; } \\
\text { - menginterpretasikan, mengkomunikasikan dan } \\
\text { menyimpulkan dengan benar dan tidak tepat informasi } \\
\text { kuantitatif yang mungkin berhubungan atau berubah atau } \\
\text { bertransformasi ke kuantitas lain baik yang dinyatakan } \\
\text { secara eksplisit maupun implisit. }\end{array}$ \\
\hline & 2 & $\begin{array}{l}\text { Tahap 2. Memecahkan masalah } \\
\text { - memecahkan masalah menggunakan metode yang benar } \\
\text { dan tidak tepat (yaitu metode aritmetika, aljabar, } \\
\text { geometri, atau statistik); } \\
\text { - memilih dan menggunakan strategi komputasi yang } \\
\text { benar dan tidak tepat untuk memecahkan masalah. }\end{array}$ \\
\hline & 2 & $\begin{array}{l}\text { Tahap 3. Memahami hasil: } \\
\text { - menentukan tingkat akurasi perhitungan yang diperlukan } \\
\text { atau kesesuaian menggunakan estimasi untuk memeriksa } \\
\text { jawaban dengan kurang tepat; } \\
\text { - mengenali keterbatasan metode matematis yang } \\
\text { digunakan dengan kurang tepat. }\end{array}$ \\
\hline $\begin{array}{l}\text { Perhitungan } \\
\text { Lateral }\end{array}$ & $\begin{array}{l}1 \\
1\end{array}$ & $\begin{array}{l}\text { Tahap 1. Memahami dan menentukan masalah: } \\
\text { - tidak memahami informasi dalam soal baik yang } \\
\text { dinyatakan secara eksplisit maupun implisit dalam } \\
\text { berbagai bentuk (rumus, kata-kata, tabel, grafik); } \\
\text { - tidak memahami masalah yang akan diselesaikan; } \\
\text { - tidak menginterpretasikan, mengkomunikasikan dan } \\
\text { menyimpulkan informasi kuantitatif yang mungkin } \\
\text { berhubungan atau berubah atau bertransformasi ke } \\
\text { kuantitas lain baik yang dinyatakan secara eksplisit } \\
\text { maupun implisit. }\end{array}$ \\
\hline
\end{tabular}




\begin{tabular}{|c|c|c|}
\hline Tingkat & Skor & Indikator \\
\hline & $\begin{array}{l}1 \\
1\end{array}$ & $\begin{array}{l}\text { Tahap 2. Memecahkan masalah } \\
\text { - memecahkan masalah tidak menggunakan metode apapun } \\
\text { (dalam penelitian ini, metode aritmetika, aljabar, } \\
\text { geometri, statistik); } \\
\text { - tidak memilih dan tidak menggunakan strategi komputasi } \\
\text { dalam memecahkan masalah. }\end{array}$ \\
\hline & $\begin{array}{l}1 \\
1\end{array}$ & $\begin{array}{l}\text { Tahap 3. Memahami hasil } \\
\text { - tidak menentukan tingkat akurasi perhitungan yang } \\
\text { diperlukan atau kesesuaian menggunakan estimasi untuk } \\
\text { memeriksa jawaban; } \\
\text { - tidak mengenali keterbatasan metode matematis yang } \\
\text { digunakan. }\end{array}$ \\
\hline & 0 & Tidak menjawab \\
\hline
\end{tabular}

\section{Writing the administration instructions}

Pada tahap ini disusun petunjuk penyelenggaraan tes yang terdiri dari petunjuk untuk pengawas tes serta petunjuk untuk peserta tes itu sendiri. Petunjuk untuk pengawas disusun dalam bentuk lembaran petunjuk pengawas dan petunjuk untuk peserta tes yang disatukan dengan lembaran soal TKPK.

\section{Conducting pilot test}

Soal TKPK, baik TKPK 1 dan TKPK 2, dan perangkat tes, yaitu petunjuk peserta tes, dan yang telah disusun diuji coba untuk memperoleh data empiris yang berguna pada pengujian kualitas perangkat tes tersebut dan butir tes. Subjek yang menjadi sasaran uji coba tes harus memiliki karakteristik yang sama dengan sasaran tes yang sebenarnya. Sasaran TKPK adalah siswa kelas VI MI/SD, maka subjek dalam uji coba tes ini adalah siswa-siswi kelas VI semester 1 MI Asih Putra yang beralamat di Kota Cimahi, Jawa Barat. Piloting test ini dilakukan kepada kelas VI-C dimana TKPK 1 diujicoba kepada 11 siswa dan TKPK 2 diujicobakan kepada 12 siswa.

\section{Conducting item analysis}

Setelah uji coba tes dilakukan, untuk mengetahui kualitas butir-butir tes tersebut sudah baik atau belum, maka perlu dilakukan analisis butir secara kuantitatif untuk mengetahui validitas, realibilitas tingkat kesukaran, dan daya pembeda. Berikut hasil perhitungan dan analisis butir soal TKPK 1 dan TKPK 2 disajikan dalam tabel 3. 
Tabel 3. Hasil Perhitungan dan Analisis Butir Soal

\begin{tabular}{|c|c|c|c|c|c|c|c|c|}
\hline \multicolumn{9}{|c|}{ TKPK 1} \\
\hline \multirow{2}{*}{$\begin{array}{c}\text { Soal } \\
\text { No- }\end{array}$} & \multicolumn{2}{|c|}{ Validitas } & \multicolumn{2}{|c|}{ Reliabilitas } & \multicolumn{2}{|c|}{ Daya Pembeda } & \multicolumn{2}{|c|}{$\begin{array}{c}\text { Tingkat } \\
\text { Kesukaran }\end{array}$} \\
\hline & Angka & Kriteria & Angka & Kriteria & Angka & Kriteria & Angka & Kriteria \\
\hline 1 & 0,541 & Cukup & \multirow{5}{*}{1,230} & \multirow{5}{*}{ Tinggi } & 0,267 & $\begin{array}{l}\text { Cukup } \\
\text { (Perlu } \\
\text { Perbai } \\
\text { kan) }\end{array}$ & 0,580 & Sedang \\
\hline 2 & 0,774 & Baik & & & 0,833 & $\begin{array}{l}\text { Sangat } \\
\text { Baik }\end{array}$ & 0,614 & Sedang \\
\hline 3 & 0,752 & Baik & & & 0,667 & $\begin{array}{l}\text { Baik } \\
\text { Cukup }\end{array}$ & 0,476 & Sedang \\
\hline 4 & 0,383 & Rendah & & & 0,267 & $\begin{array}{l}\text { (Perlu } \\
\text { Perbai } \\
\text { kan) }\end{array}$ & 0,424 & Sedang \\
\hline 5 & 0,747 & Baik & & & 0,467 & Baik & 0,541 & Sedang \\
\hline \multicolumn{9}{|c|}{ TKPK 2} \\
\hline \multirow{2}{*}{$\begin{array}{l}\text { Soal } \\
\text { No- }\end{array}$} & \multicolumn{2}{|c|}{ Validitas } & \multicolumn{2}{|c|}{ Reliabilitas } & \multicolumn{2}{|c|}{ Daya Pembeda } & \multicolumn{2}{|c|}{$\begin{array}{c}\text { Tingkat } \\
\text { Kesukaran }\end{array}$} \\
\hline & Angka & Kriteria & Angka & Kriteria & Angka & Kriteria & Angka & Kriteria \\
\hline 1 & 0,503 & Cukup & & & 0,375 & $\begin{array}{l}\text { Cukup } \\
\text { (Perlu } \\
\text { Perbai } \\
\text { kan) }\end{array}$ & 0,417 & Sedang \\
\hline 2 & 0,888 & Baik & 1,232 & Tinggi & 0,750 & $\begin{array}{l}\text { Sangat } \\
\text { Baik }\end{array}$ & 0,437 & Sedang \\
\hline 3 & 0,780 & Baik & & & 0,625 & Baik & 0,413 & Sedang \\
\hline 4 & 0,934 & $\begin{array}{l}\text { Sangat } \\
\text { Baik }\end{array}$ & & & 1 & $\begin{array}{l}\text { Sangat } \\
\text { Baik }\end{array}$ & 0,448 & Sedang \\
\hline 5 & 0,681 & Cukup & & & 0,625 & Baik & 0,321 & Sedang \\
\hline
\end{tabular}

Pada TKPK 1, terdapat satu butir soal yaitu soal nomor 4 yang memiliki validitas rendah, satu soal memiliki validitas cukup yaitu nomor 1 dan tiga soal memiliki validitas baik yaitu nomor 2, 3, dan 5 . Sedangkan, reliabilitas soal menunjukkan hasil yang cukup sangat tinggi. Daya pembeda butir soal menunjukkan hasil yang beragam namun masih dalam kategori yang baik. Mulai dari nomor 1 dan 4 memiliki daya pembeda yang cukup dengan catatan perlu ada perbaikan jika digunakan, nomor 3 dan 5 memiliki daya pembeda yang baik, hingga nomor 2 memiliki daya pembeda yang sangat baik. Tingkat kesukaran setiap soal pada TKPK 1 dikategorikan memiliki tingkat kesukaran yang sedang. 
Pada TKPK 2, tidak terdapat soal yang memiliki validitas yang rendah, dua soal memiliki validitas cukup yaitu nomor 1 dan 5 dan dua soal memiliki validitas baik yaitu nomor 2 dan 3 dan terdapat satu soal yang memiliki validitas sangat baik yaitu soal nomor 4. Sedangkan, reliabilitas soal menunjukkan hasil yang cukup sangat tinggi. Daya pembeda butir soal menunjukkan hasil yang beragam namun masih dalam kategori yang baik. Mulai dari nomor 1 memiliki daya pembeda yang cukup dengan catatan perlu ada perbaikan jika digunakan, nomor 3 dan 5 memiliki daya pembeda yang baik, hingga nomor 2 dan 4 memiliki daya pembeda yang sangat baik. Tingkat kesukaran setiap soal pada TKPK 2 dikategorikan memiliki tingkat kesukaran yang sedang.

\section{Revising the test}

Berdasarkan hasil analisis butir soal, peneliti merevisi butir yang kurang baik. Pengambilan keputusan terhadap butir-butir yang perlu direvisi dilakukan dengan menggunakan beberapa pertimbangan hasil analisis validitas $\left(r_{x y}\right)$, realibilitas $\left(r_{11}\right)$, dan daya pembeda $(D P)$. Apabila dua dari tiga kriteria butir tes yang baik dapat terpenuhi atau konsisten, maka butir tes tersebut dapat digunakan.

Tabel 4. Kesimpulan hasil analisis butir soal

\begin{tabular}{|c|c|c|c|c|c|c|}
\hline \multicolumn{7}{|c|}{ TKPK 1} \\
\hline $\begin{array}{l}\text { Soal } \\
\text { No- }\end{array}$ & Validitas & Reliabilitas & $\begin{array}{c}\text { Daya } \\
\text { Pembeda }\end{array}$ & $\begin{array}{c}\text { Tingkat } \\
\text { Kesukaran }\end{array}$ & $\begin{array}{c}\text { Penggunaan } \\
\text { Butir Soal }\end{array}$ & Kesimpulan \\
\hline 1 & Cukup & & $\begin{array}{l}\text { Cukup } \\
\text { (Perlu } \\
\text { Perbaikan) }\end{array}$ & Sedang & $\begin{array}{l}\text { Digunakan } \\
\text { dengan } \\
\text { perbaikan }\end{array}$ & $\begin{array}{l}\text { Rancangan } \\
\text { TKPK } 1 \\
\text { digunakan }\end{array}$ \\
\hline 2 & Baik & & Sangat Baik & Sedang & Digunakan & dengan \\
\hline 3 & Baik & Tinggi & Baik & Sedang & Digunakan & memperbaiki \\
\hline 4 & Rendah & & $\begin{array}{l}\text { Cukup } \\
\text { (Perlu } \\
\text { Perbaikan) }\end{array}$ & Sedang & $\begin{array}{l}\text { Digunakan } \\
\text { dengan } \\
\text { perbaikan }\end{array}$ & $\begin{array}{l}\text { butir soal } \\
\text { nomor } 1 \text { dan } \\
4\end{array}$ \\
\hline 5 & Baik & & Baik & Sedang & Digunakan & \\
\hline
\end{tabular}




\begin{tabular}{|c|c|c|c|c|c|c|}
\hline \multicolumn{7}{|c|}{ TKPK 2} \\
\hline $\begin{array}{l}\text { Soal } \\
\text { No- }\end{array}$ & Validitas & Reliabilitas & $\begin{array}{c}\text { Daya } \\
\text { Pembeda }\end{array}$ & $\begin{array}{c}\text { Tingkat } \\
\text { Kesukaran }\end{array}$ & $\begin{array}{c}\text { Penggunaan } \\
\text { Butir Soal }\end{array}$ & Kesimpulan \\
\hline 1 & Cukup & & $\begin{array}{l}\text { Cukup } \\
\text { (Perlu } \\
\text { Perbaikan) }\end{array}$ & Sedang & $\begin{array}{l}\text { Digunakan } \\
\text { dengan } \\
\text { perbaikan }\end{array}$ & $\begin{array}{l}\text { Rancangan } \\
\text { TKPK } 2 \\
\text { digunakan }\end{array}$ \\
\hline 2 & Baik & & Sangat Baik & Sedang & Digunakan & dengan \\
\hline 3 & Baik & Tinggl & Baik & Sedang & Digunakan & memperbaiki \\
\hline 4 & $\begin{array}{l}\text { Sangat } \\
\text { Baik }\end{array}$ & & Sangat Baik & Sedang & Digunakan & $\begin{array}{l}\text { butir soal } \\
\text { nomor } 1\end{array}$ \\
\hline 5 & Cukup & & Baik & Sedang & Digunakan & \\
\hline
\end{tabular}

Sebaliknya apabila dua dari tiga kriteria butir tidak dapat memenuhi kualitas butir yang baik maka butir tes perlu diganti atau direvisi.

Dalam tabel 4 menunjukkan bahwa rancangan TKPK 1 perlu dilakukan perbaikan pada butir soal nomor 1 dan 4. Sedangkan pada rancangan TKPK 2 butir soal nomor 1 yang perlu diperbaiki. Oleh karena itu, peneliti melakukan perbaikan dan menghasilkan draf 3 soal TKPK. Berikut tabel 5 memaparkan soal yang sebelum dan sesudah direvisi.

Tabel 5. Butir Soal Sebelum dan Sesudah Revisi

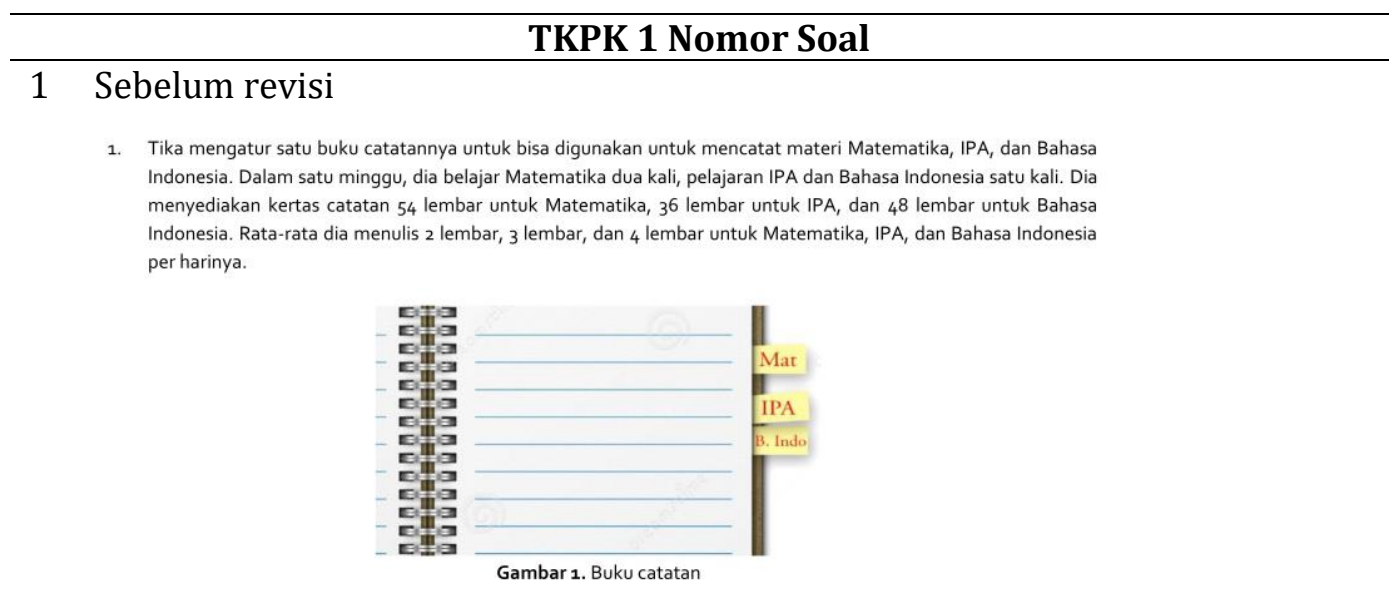

Empat minggu setelah pembelian buku catatan, berapa lembarkah yang telah digunakan oleh Tika untuk menulis materi Matematika, IPA, dan Bahasa Indonesia? 


\section{Sesudah revisi}

1. Tika mengatur catatan materi Matematika, IPA, dan Bahasa Indonesia dalam satu buku catatan. Setiap minggu, dia belajar Matematika dua kali, belajar IPA dan Bahasa Indonesia satu kali. Dalam buku catatan tersebut, dia menyediakan 54 lembar untuk catatan Matematika, 36 lembar untuk catatan IPA, dan 48 lembar untuk catatan Bahasa Indonesia. Rata-rata dia menulis 2 lembar untuk Matematika, 3 lembar untuk IPA, dan 4 lembar untuk Bahasa Indonesia setiap harinya.

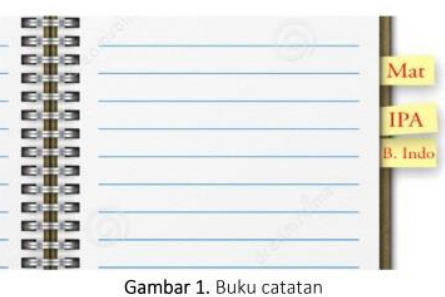

Empat minggu setelah menggunakan buku catatan tersebut, berapa lembarkah yang belum digunakan untuk mencatat oleh Tika?

2 Sebelum revisi

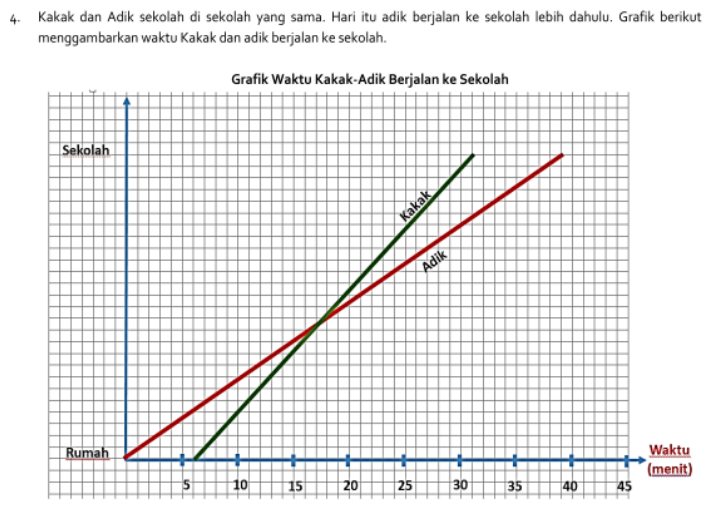

Pada menit ke berapa Kakak dapat menyusul adik?

\section{Sesudah revisi}

4. Kakak dan Adik sekolah di sekolah yang sama. Hari itu adik berjalan ke sekolah lebih dahulu. Grafik beriku mengembarkan waktu Kakak dan adik berialan ke sekol th.

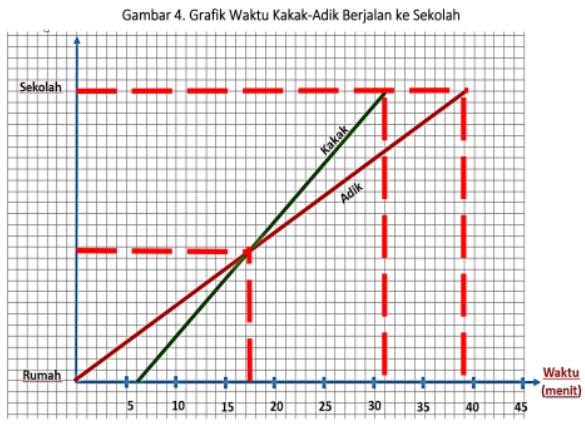




\section{TKPK 2 Nomor Soal}

\section{Sebelum revisi}

1. Kucing Ana dimandikan 4 hari sekali, sedangkan kucing Boni dimandikan 6 hari sekali. Pada tanggal 10 Maret 2017 kucing keduanya dimandikan.

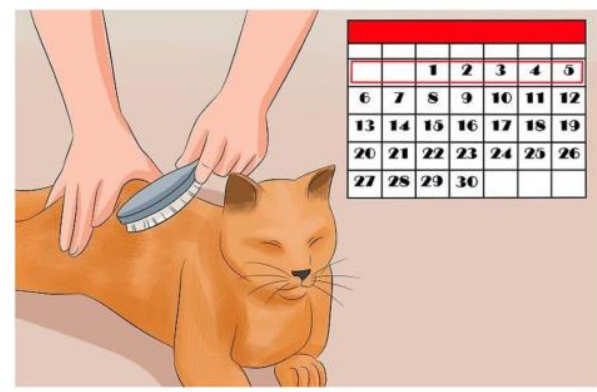

Pada tanggal berapa kedua kucing dimandikan di tanggal yang sama berikutnya?

\section{Sesudah revisi}

1. Pada tanggal 10 Maret 2017 kucing Ana dan kucing Boni dimandikan bersama-sama. Jika Ana mempunyai kebiasaan memandikan kucingnya 4 hari sekali, sedangkan Boni memandikan kucingnya 6 hari sekali.

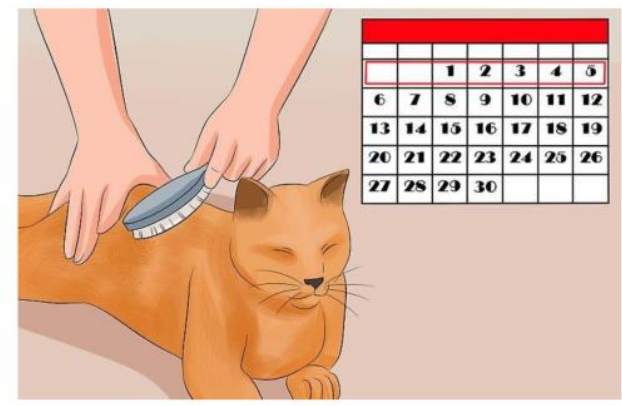

Pada tanggal berapa lagi berikutnya Ana dan Boni memandikan kucingnya bersama-sama?

Perangkat tes lain, petunjuk peserta tes dinilai cukup baik dan efektif mengarahkan peserta tes dalam mengerjakan dan menuliskan jawaban soal. Hal tersebut terlihat pada jawaban yang dituliskan siswa di lembar jawaban sudah sesuai dengan petunjuk yang dicantumkan pada lembar soal.

\section{Kualitas Soal TKPK}

Dua rancangan soal TKPK yang dikembangkan memiliki kualitas yang cukup baik. Hal itu dapat dilihat dari hasil perhitungan dan analisis butir soal yang telah dilakukan pada tahap conducting item analysis.

\section{Kualitas soal TKPK 1}

Berikut disajikan kualitas butir soal TKPK. 
Tabel 5. Kualitas Butir Soal TKPK 1

\begin{tabular}{|c|c|c|c|c|c|c|c|c|c|}
\hline \multirow{3}{*}{$\begin{array}{c}\text { Soal } \\
\text { No- }\end{array}$} & \multicolumn{8}{|c|}{ TKPK 1} & \multirow{3}{*}{$\begin{array}{c}\text { Kualitas } \\
\text { Butir } \\
\text { Soal }\end{array}$} \\
\hline & \multicolumn{2}{|c|}{ Validitas } & \multicolumn{2}{|c|}{ Reliabilitas } & \multicolumn{2}{|c|}{ Daya Pembeda } & \multicolumn{2}{|c|}{$\begin{array}{c}\text { Tingkat } \\
\text { Kesukaran }\end{array}$} & \\
\hline & Angka & Kriteria & Angka & Kriteria & Angka & Kriteria & Angka & Kriteria & \\
\hline 1 & 0,541 & Cukup & & & 0,267 & $\begin{array}{l}\text { Cukup } \\
\text { (Perlu } \\
\text { Perbaikan) }\end{array}$ & 0,580 & Sedang & $\begin{array}{l}\text { Cukup } \\
\text { Baik }\end{array}$ \\
\hline 2 & 0,774 & Baik & & & 0,833 & $\begin{array}{l}\text { Sangat } \\
\text { Baik }\end{array}$ & 0,614 & Sedang & $\begin{array}{l}\text { Sangat } \\
\text { Baik }\end{array}$ \\
\hline 3 & 0,752 & Baik & 1,230 & Tinggl & 0,667 & Baik & 0,476 & Sedang & Baik \\
\hline 4 & 0,383 & $\begin{array}{l}\text { Renda } \\
\mathrm{h}\end{array}$ & & & 0,267 & $\begin{array}{l}\text { Cukup } \\
\text { (Perlu } \\
\text { Perbaikan) }\end{array}$ & 0,424 & Sedang & $\begin{array}{l}\text { Kurang } \\
\text { Baik }\end{array}$ \\
\hline 5 & 0,747 & Baik & & & 0,467 & Baik & 0,541 & Sedang & Baik \\
\hline
\end{tabular}

Soal TKPK 1 memiliki reliabilitas yang tinggi, maka TKPK 1 sangat ajeg dalam menilai kemampuan penalaran kuantitatif siswa selama aspek yang diukur dalam diri subjek memang belum berubah. Dalam kesempatan kapanpun soal TKPK 1 akan memberikan hasil yang relatif sama terhadap setiap peserta tes.

Kualitas berikutnya adalah validitas butir soal. Butir soal yang valid, maka butir soal tersebut dapat memberikan informasi dengan tepat tentang peserta tes mana yang belum atau sudah mencapai kemampuan yang ditetapkan. Butir soal nomor 4 memiliki validitas yang rendah, sehingga soal tersebut memiliki kemampuan yang rendah untuk memberikan informasi tentang kemampuan penalaran kuantitatif siswa. Butir soal nomor 1 memiliki validitas cukup, sehingga soal tersebut cukup tepat memberikan informasi tentang kemampuan penalaran kuantitatif siswa. Butir soal nomor Butir soal nomor 2, 3 dan 5 memiliki validitas baik, sehingga soal tersebut tepat memberikan informasi tentang kemampuan penalaran kuantitatif siswa.

Daya pembeda menunjukkan kemampuan suatu soal untuk membedakan antara peserta tes yang memiliki kemampuan penalaran kuantitatif yang tinggi dengan peserta tes memiliki kemampuan penalaran kuantitatif yang kurang. Secara logis, peserta tes yang memiliki kemampuan yang tinggi akan lebih mampu menjawab (mendapat skor lebih baik) dibanding dengan peserta tes yang kurang. Daya pembeda butir soal nomor 1 dan 4 cukup baik, butir soal nomor 3 dan 5 memiliki daya pembeda yang baik, sedangkan butir soal nomor 2 memiliki daya pembeda yang sangat baik. 
Tingkat kesukaran kelima soal dalam TKPK 1 dikategorikan memiliki tingkat kesukaran yang sedang. Ini menunjukkan soal-soal tersebut tidak terlalu mudah ataupun tidak terlalu sukar.

Dari keempat ukuran kualitas butir soal, validitas, reliabilitas, daya pembeda dan tingkat kesukaran, butir soal nomor 4 memiliki kualitas yang kurang baik, butir soal nomor 1 memiliki kualitas yang cukup baik, dan butir soal nomor 3 dan 5 memiliki kualitas yang baik, dan butir soal nomor 2 memiliki kualitas yang sangat baik. Soal TKPK 1 dapat digunakan untuk mengukur kemampuan penalaran kuantitatif siswa kelas VI MI/SD dengan perbaikan pada butir soal nomor 4.

\section{Kualitas soal TKPK 2}

Berikut disajikan kualitas butir soal TKPK 2.

Tabel 6. Kualitas butir soal TKPK 2

\begin{tabular}{|c|c|c|c|c|c|c|c|c|c|}
\hline \multirow{3}{*}{$\begin{array}{l}\text { Soal } \\
\text { No- }\end{array}$} & \multicolumn{8}{|c|}{ TKPK 2} & \multirow{3}{*}{$\begin{array}{c}\text { Kualitas } \\
\text { Butir } \\
\text { Soal }\end{array}$} \\
\hline & \multicolumn{2}{|c|}{ Validitas } & \multicolumn{2}{|c|}{ Reliabilitas } & \multicolumn{2}{|c|}{ Daya Pembeda } & \multicolumn{2}{|c|}{$\begin{array}{c}\text { Tingkat } \\
\text { Kesukaran }\end{array}$} & \\
\hline & Angka & Kriteria & Angka & Kriteria & Angka & Kriteria & Angka & Kriteria & \\
\hline 1 & 0,503 & Cukup & & & 0,375 & $\begin{array}{l}\text { Cukup } \\
\text { (Perlu } \\
\text { Perbaikan) }\end{array}$ & 0,417 & Sedang & $\begin{array}{l}\text { Cukup } \\
\text { Baik }\end{array}$ \\
\hline 2 & 0,888 & Baik & 1,232 & Tinggi & 0,750 & $\begin{array}{l}\text { Sangat } \\
\text { Baik }\end{array}$ & 0,437 & Sedang & $\begin{array}{l}\text { Sangat } \\
\text { Baik }\end{array}$ \\
\hline 3 & 0,780 & Baik & & & 0,625 & Baik & 0,413 & Sedang & Baik \\
\hline 4 & 0,934 & $\begin{array}{l}\text { Sangat } \\
\text { Baik }\end{array}$ & & & 1 & $\begin{array}{l}\text { Sangat } \\
\text { Baik }\end{array}$ & 0,448 & Sedang & $\begin{array}{l}\text { Sangat } \\
\text { Baik }\end{array}$ \\
\hline 5 & 0,681 & Cukup & & & 0,625 & Baik & 0,321 & Sedang & Baik \\
\hline
\end{tabular}

Soal TKPK 2 memiliki reliabilitas yang tinggi, maka TKPK 2 sangat ajeg dalam menilai kemampuan penalaran kuantitatif siswa selama aspek yang diukur dalam diri subjek memang belum berubah. Dalam kesempatan kapanpun soal TKPK 2 akan memberikan hasil yang relatif sama terhadap setiap peserta tes.

Kualitas berikutnya adalah validitas butir soal. Butir soal yang valid, maka butir soal tersebut dapat memberikan informasi dengan tepat tentang peserta tes mana yang belum atau sudah mencapai kemampuan yang ditetapkan. Butir soal nomor 1 dan 5 memiliki validitas cukup, sehingga soal tersebut cukup tepat memberikan informasi tentang kemampuan penalaran kuantitatif siswa. Butir soal nomor Butir soal nomor 2 dan 3 memiliki validitas baik, sehingga soal tersebut tepat memberikan informasi tentang kemampuan penalaran kuantitatif siswa. Butir soal nomor Butir 
soal nomor 4 memiliki validitas sangat baik, sehingga soal tersebut sangat tepat memberikan informasi tentang kemampuan penalaran kuantitatif siswa.

Daya pembeda menunjukkan kemampuan suatu soal untuk membedakan antara peserta tes yang memiliki kemampuan penalaran kuantitatif yang tinggi dengan peserta tes memiliki kemampuan penalaran kuantitatif yang kurang. Secara logis, peserta tes yang memiliki kemampuan yang tinggi akan lebih mampu menjawab (mendapat skor lebih baik) dibanding dengan peserta tes yang kurang. Daya pembeda butir soal nomor 1 cukup baik, butir soal nomor 3 dan 5 memiliki daya pembeda yang baik, sedangkan butir soal nomor 2 dan 4 memiliki daya pembeda yang sangat baik.

Tingkat kesukaran kelima soal dalam TKPK 2 dikategorikan memiliki tingkat kesukaran yang sedang. Ini menunjukkan soal-soal tersebut tidak terlalu mudah ataupun tidak terlalu sukar.

Dari keempat ukuran kualitas butir soal, validitas, reliabilitas, daya pembeda dan tingkat kesukaran, butir soal nomor 1 memiliki kualitas yang cukup baik, dan butir soal nomor 3 dan 5 memiliki kualitas yang baik, dan butir soal nomor 2 dan 4 memiliki kualitas yang sangat baik. Soal TKPK 1 dapat digunakan untuk mengukur kemampuan penalaran kuantitatif siswa kelas VI MI/SD.

\section{SIMPULAN}

Perangkat tes kemampuan penalaran kuantiatif dikembangkan sesuai dengan indikator kemampuan penalaran kuantitatif. Penelitian ini dilakukan untuk mengembangkan dan menguji kualitas perangkat tes tersebut sehingga layak digunakan untuk mengukur kemampuan penalaran kuantitatif siswa kelas VI MI/SD. Instrumen tes kemampuan penalaran kuantitatif (TKPK) meliputi lembar soal (petunjuk peserta tes dan soal), lembar jawaban, pedoman penskoran, pedoman pengawas dan jawaban dan alternatif penyelesaian. Pengembangan tes kemampuan penalaran kuantitatif (TKPK) siswa kelas VI MI/SD dilakukan dengan merancang dua rancangan, yaitu TKPK 1 dan TKPK 2 dan melalui tujuh tahap, yaitu (1) mendefinisikan indikator kemampuan penalaran kuantitatif, konten tes dan konteks masalah yang digunakan; (2) mengkonstruk kisi-kisi, format pertanyaan dan jawaban, bentuk penyelenggaraan dan cara penskoran; (3) menyusun butir-butir soal tes berupa dua rancangan soal, TKPK 1 dan TKPK 2 yang masing-masing terdiri atas lima butir soal sesuai dengan format tes dan indikator pencapaian kompetensi yang telah dirancang dan disusun pula pedoman penskoran; (4) menyusun petunjuk penyelenggaraan tes yang terdiri dari petunjuk untuk pengawas tes serta petunjuk 
untuk peserta tes; (5) uji coba instrumen tes baik TKPK 1 dan TKPK 2; (6) analisis butir soal secara kuantitatif; dan (7) merevisi butir soal yang kurang baik. Dua rancangan soal TKPK yang dikembangkan memiliki kualitas yang cukup baik. TKPK 1 dapat digunakan dengan perbaikan, sedangkan TKPK 2 dapat langsung digunakan.

\section{UCAPAN TERIMA KASIH}

Terimakasih kepada pihak STAI Siliwangi Bandung, mulai dari Ketua, Pembantu Ketua I, Pembantu Ketua 2, staf dan rekan sejawat dosen yang telah memberi dukungan hingga penelitian ini dapat dilaksanakan dengan lancar. Terimakasih juga kepada validator yang telah membantu memvalidasi kualitas instrumen tes kemampuan penalaran.

\section{DAFTAR PUSTAKA}

Agustinus, S. (2013, December 9). Penalaran kuantitatif (quantitative reasoning) dalam pemecahan masalah matematika. Seminar Nasional Matematika dan Pendidikan Matematika.

Carroll, J. B. (1993). Human Cognitive Abilities. Cambridge University Press. https://doi.org/10.1017/CB09780511571312

Dwyer, C. A., Gallagher, A., Levin, J., \& Morley, M. E. (2003). What is quantitative reasoning? Defining the construct for assessment purposes. ETS Research Report Series, 2003(2), i-48. https://doi.org/10.1002/j.23338504.2003.tb01922.x

Ellis, A. B. (2011). Algebra in the middle school: Developing functional relationships through quantitative reasoning. In Early algebraization (pp. 215-238). Springer, Berlin, Heidelberg. https://doi.org/10.1007/978-3-642-17735-4 13

Firdaus, Z. (2013). Identifikasi Kemampuan Penalaran Spasial dan Kuantitatif Siswa SDI Miftahul Ulum Surabaya pada Tahap Operasi Konkret Piaget. UIN Sunan Ampel Surabaya.

Fu'adiah, D. (2018). Pengembangan penalaran kuantitatif di sekolah dasar untuk mengembangkan berpikir aljabar di sekolah menengah pertama. Jurnal Riset Pendidikan dan Inovasi Pembelajaran Matematika (JRPIPM), 1(1). https://doi.org/10.26740/irpipm.v1n1.p19-29

Grawe, N. D. (2011). Beyond math skills: Measuring quantitative reasoning in context. New Directions for Institutional Research, 2011(149), 41-52. https://doi.org/10.1002/ir.379

Indonesia, P.R. (2006). Permendiknas Nomor 23 Tahun 2006 tentang Standar Kompetensi Lulusan Untuk Satuan Pendidikan Dasar dan Menengah.

Harel, G., \& Sowder, L. (1998). Students' proof schemes: Results from exploratory studies (pp. 234-283). https://doi.org/10.1090/cbmath/007/07

Hoffman, K., Leupen, S., Dowell, K., Kephart, K., \& Leips, J. (2016). Development and assessment of modules to integrate quantitative skills in introductory biology courses. CBE Life Sciences Education, 15(2). https://doi.org/10.1187/cbe.15$\underline{09-0186}$ 
Jack, J. P., \& Thompson, P. W. (2017). 4 Quantitative reasoning and the development of algebraic reasoning. In Algebra In The Early Grades (pp. 95-132). Routledge. https://doi.org/10.4324/9781315097435-5

Kabael, T., \& Akin, A. (2016). Problem solving strategies and quantitative reasoning skills in solving algebraic verbal problems of seventh grade students. Kastamonu Education Journal, 24(2), 875-894.

McIntire, Sandra, A., Miller, \& Leslie, A. (2006). Foundations of psychological testing: A practical approach (Second Edition). SAGE Publications.

Moore, K., Carlson, M., \& Oehrtman, M. (2009). The Role of qualitative reasoning in solving applied precalculus problems. Twelfth Annual Special Interest Group of the Mathematical Association of America on Research in Undergraduate Mathematics Education.

Nunes, T., \& Bryant, P. (2021). Promoting quantitative reasoning in elementary school. In Using Mathematics to Understand the World. https://doi.org/10.4324/9780429265815-5

Tian, Z., \& Huang, X. (2009). A Study of Children's Spatial Reasoning and Quantitative Reasoning Abilities. Journal of Mathematics Education, 2(2), 80-93.

Conflict of Interest Statement: The authors declare that the research was conducted in the absence of any commercial or financial relationships that could be constructed as a potential conflict of interest. 